\title{
RELIGIOUS ARCHITECTURE AS AN INSTRUMENT FOR URBAN RENEWAL. TWO RELIGIOUS COMPLEXES FROM THE SAADIAN PERIOD IN MARRAKESH
}

\section{$\underline{\text { 1. Introduction }^{1}}$}

At the beginning of the sixteenth century and after a long period of decay, the city of Marrakesh reclaimed its status as a capital city with the rise to power of the Saadian dynasty and the establishment of a new state, bringing about major urban development and leaving a lasting legacy of material vestiges. However we must highlight the reign of sultan 'Abdallāh al-Ghālib (1557-1574) during which the city experienced a period of significant growth. The medina had shrunk so considerably before the Saadian period that it no longer had the minimum facilities required for a city of its importance, therefore, immediately after his arrival from Fez, 'Abdallāh created the framework to modernize Marrakesh. Even though his brother and future sultan Ahmad al-Manșūr is the most renowned sovereign of the dynasty thanks to the sponsorship of superb buildings such as the al-Badī' palace, it was 'Abdallāh who invested the most in the construction of religious and civil facilities, as well as in projects that reorganized and restructured the capital.

This paper is divided into two parts. In the first, the historical context of the city is presented from the beginning of the Saadian period until 'Abdallāh al-Ghālib's ascent to the throne, followed by a list of all of the architectural works that are attributed to his reign by written sources. We consider it pertinent to think of these interventions as parts of a unitary plan the goal of which was the renewal of the city, a plan we will refer to as "The Project of "Abdallāh al-Ghālib". In this section, the impact that the Saadians had on the urban and architectural development of Marrakesh is highlighted, and a relationship is established between one of the country's most politically stable periods and the city's growth.

Once this framework has been established, the second part focuses on two of the most important complexes built in Marrakesh during the Saadian period, one of which corresponds without a doubt to 'Abdallāh's "Project". We are referring to two religious facilities the importance of which rests upon how they became a model to follow, their monumentality and the impact they had on the urban landscape. The al-Muwāssīn and Bāb Dukkāla religious complexes share the same architectural layout: a congregational mosque surrounded by a wide range of annexes, with both religious and secular uses, some of which were also used as sources of income in order to make the complexes financially sustainable. They are characterized by their layout, the choice of their settings and the strategies used to connect the buildings with the preexisting urban tissue. The analysis of the two complexes and their respective surroundings has enabled us to assess the impact of their construction in two different neighborhoods of the city and to consider that they also served as instruments for urban renewal. Lastly, these parallel case studies will help to establish the origins of these Saadian architectural models and the innovations they introduced by comparing them with other examples throughout the Maghreb.

\footnotetext{
${ }^{1}$ This paper is part of the research project HAR2014-53006-P, “Arquitectura saadí: la pervivencia de al-Andalus en el Magreb", funded by the Ministerio de Economía, Industria y Competitividad, Programa Estatal de Fomento de la Investigación Científica y Técnica de Excelencia, with support from the European Union FEDER program, and directed by Antonio Almagro Gorbea $\mathrm{PhD}$ at the Escuela de Estudios Árabes de Granada (Consejo superior de Investigaciones Científicas). I would like to thank Antonio Almagro, Alfonso Jiménez, María Ángeles Utrero for their attentive reading of the text as well as for their insight and suggestions. This article has been translated from Spanish into English by Vincent Morales Garoffolo.
} 


\section{Historical context}

After its foundation by the Almoravids in the eleventh century, the city of Marrakesh became the capital of an empire that included the Maghreb, Ifriqiyya and al-Andalus, a territorial expanse that was maintained during the Almohad period. However, after the collapse of the Almohad regime, Marrakesh became a mere regional capital and its situation worsened during the fifteenth century with the extinction of the Marinid dynasty and the period of decomposition and anarchy that followed. This is known as the "marabout" period due to the proliferation of zawiyas, which were religious institutions that became a form of government solely at a local and regional level. As for Marrakesh, in the sixteenth century it had fallen into the hands of the Hintāta, a Berber tribe that established an Emirate.

Within this context, a new power rose in the South, led by a Sharifian family that had settled at the Wādī Sūs, commanding the resistance against the Portuguese incursions that proliferated along the Atlantic coast. The success of this lineage produced the Saadian dynasty and in 1521, its second sovereign, Ahmad al-A raj (1517-1544) entered Marrakesh and vanquished the Hintāta emir. Muhammad al-Šaykh (1544-1557) deposed his brother Ahmad and continued expanding the Saadian domains until the entire country was united. During that time, Marrakesh became the main center of military operations, but it was not fully constituted as a capital city ${ }^{2}$. Leo Africannus provides an interesting description of the city at the time, recounting that it was severely under-populated, that the interior of the medina had become ruralized with the proliferation of cultivated areas and that the outskirts of the city were unsafe ${ }^{3}$.

When the death of Muhammad was announced, the governor, 'Alī ibn Abū Bakr, killed al-Šaykh's dethroned brother Ahmad al-A'raj and his male sons with the aim of ensuring the succession of Mawlāy 'Abdallāh al-Ghālib bi-Llāh (1557-1574) who, up until then had been the khaliff or lieutenant of the city of Fez and the legitimate heir ${ }^{4}$. The battle of Wādī al-Laban against the Ottomans took place at the beginning of his reign, which he triumphantly won. From then on and throughout his rule there were no other military conflicts. In fact, he tried to remain neutral during the disputes between Spain, Portugal and the Ottoman Empire, making the most of the international roles of these powers to maintain peace and the territorial integrity of his country ${ }^{5}$. The result was that Marrakesh became at long last the capital of al-Maghrib al-Aqsà and the prosperity that ensued made wide spread construction activity possible ${ }^{6}$. Morevoer, 'Abdallāh was able to modernize the army, maintain a peaceful relationship with the zawiyas and take in many exiled moriscos ${ }^{7}$.

\footnotetext{
${ }^{2}$ In fact, Muḥammad al-Šaykh hesitated between locating the capital in Fez or Marrakesh, which is understandable since the country was still undergoing a process of unification and formation.

${ }^{3}$ Leo Africannus finished his work in 1526, therefore the information used to describe Marrakesh is from before that year and his acquaintance with the city dates to the reign of Ahmad al-A'raj at the very latest. Leo Africanus, Descripción general del Africa y de las cosas peregrinas que allí hay (Granada: Fundación El Legado Andalusí, 2004), p.61.

${ }^{4}$ Muhammad al-Ifrānī, Nozhet-Elhâdi: histoire de la dynastie saadienne au Maroc, ed. O. Houdas (Paris: Enest Léroux, 1988-1989), vol.1, p.22.

${ }^{5}$ Nabil Mouline, Le Califat imaginaire d'Ahmad al-Mansûr: pouvoir et diplomatie au Maroc au XVIe siècle (Paris: Presses Universitaires de France, 2009), p.36.

${ }^{6}$ Al-Ifrānī indicates that 'Abdallāh was faced with enormous costs in order to build his projects. Al-Ifrānī, Nozhet-Elhâdi, 51. Likewise, the commemorative inscriptions that appear in Saadian burial grounds state that he was a builder of mosques and madrasas (bānī al-masājidwa al-madāris). Gaston Deverdun, Inscriptions arabes de Marrakech (Rabat: Editions Techniques Nord-Africaines, 1956), p.77.

${ }^{7}$ The economic and demographic growth that the city enjoyed during the stable reigns of "Abdallāh al-Ghālib and Aḥmad al-Manșūr brought about the development of the old neighborhoods and even the creation of new
} 
Mawlāy' Abdallāh's death brought years of solid and stable governments to an end. He was succeeded by his son Muhammad al-Mutawakkil, leading to the first Saadian crisis, which ended in the battle of the Three Kings or of Wādī al-Makhāzin, won by the second great Saadian ruler, Aḥmad al-Manșūr (1578-1603).

\section{3. 'Abdallāh al-Ghālib's Project}

Written sources tell us that 'Abdallāh's rule was marked by one of the most stable and peaceful periods of governance of the Saadian dynasty, enabling widespread investment in the construction of large civil and religious facilities ${ }^{8}$. In fact, some of the buildings from the time still stand and they are some of the most important monuments in Marrakesh. Most of the information regarding the different interventions that can be attributed to 'Abdallāh comes from Luis del Mármol Carvajal's Descripción general de África. Mármol was a Spanish captive who became familiarized with the city during those years, and he provides a fairly complete depiction of its urban landscape. Likewise, Arab accounts have enabled us to clearly identify some of the buildings and to determine their original names.

The significant amount of interventions from that period that have been identified, their monumentality and their historical context lead us to think that they are all part of a unitary project aimed at the architectural and urban renewal of Marrakesh, the reconstruction of certain infrastructures and the modernization of the city to foster its demographic growth. In order to fulfill this enterprise, 'Abdallāh may have used the city of Fez as an example, which, at the time, was the most developed in Morocco after being the capital of the Marinid dynasty for almost two centuries. It was also a city he was well acquainted with after serving as its khalifa before his ascent to the throne. Specifically, we will see how many of the interventions carried out in Marrakesh clearly resemble those in the palatial city of Fās alJadīd (New Fez).

\subsection{Qaṣba}

The alcazaba (Qașba) of Marrakesh is a large, walled-in and autonomous enclosure attached to the medina on the south (Figure 1.A). It dates back to the time of the Almohad caliph Ya 'qūb al-Manșūr, who had it built to accommodate the administrative, courtesan and military functions of his government. The monumental gate of Bāb Agnāw, also from the Almohad period, is located to the northwest. It led into the alcazaba from within the medina next to the Bāb al-Rubb gate, one of the main entrances of the city (Figure 1.13). After a long

ones. Some of the names they received have been linked with the Saadian period: Darb Dabāš̄i, Janān Ibn Šagrā, Darb Šantūf, al-Ṭāl'a, Darb al-Ṭliṭlī and specially the hawma of al-Muwāssīn, Bāb Dukkāla and Riyāḍ alZaytūn. Raji Elillah, La Ville de Marrakech sous les Sa'adiens (16-17ème siècles): L'activité architecturale et le développement urbain (Universidad de Paris-Sorbonne, 1996), Tesis Doctoral, pp.237-241.

${ }^{8}$ The other great builder of the dynasty was his brother Aḥmad al-Manșūr. However, he concentrated his efforts on raising the al-Badī' palace and on the city's defensive architecture. See Antonio Almagro "Los alzados del patio del palacio al-Badi' de Marrakech. ¿Diseño y construcción por el método de prueba y error'?”, Arqueología de la Arquitectura 14 (2017): e055. doi: http://dx.doi.org/10.3989/arq.arqt.2017.012. Antonio Almagro, "The Saadian Fortifications of Ahmad Al-Mansur in Morocco", in Defensive Architecture of the Mediterranean. XV to XVIII Centuries: Vol. V: Proceedings of the International Conference on Modern Age Fortifications of the Mediterranean Coast, FORTMED 2017, ed. Víctor Echarri (Alacant: Publicacions Universitat d'Alacant, 2017), pp. 109-118. 
period of abandonment, in the sixteenth century, the Saadians settled in Marrakesh and reoccupied the alcazaba9 .

Due to the lack of archaeological information, we know of the refurbishment carried out by 'Abdallāh al-Ghālib only through written sources and graphical documents. Among the latter, the plan drawn up by a Portuguese friar in 1585 stands out ${ }^{10}$. In it, a highly developed form of the alcazaba is represented, including the interventions carried out at later dates by Aḥmad al-Manșūr ${ }^{11}$. Besides this, Leo Africannus's testimony, from before 'Abdallāh's rule, describes a walled alcazaba, with gates, a large mosque and a madrasa, despite stating that most of the palaces and gardens were abandoned ${ }^{12}$. However, Mármol draws a different picture, revealing the building and refurbishment projects carried out by 'Abdallāh and depicting a highly evolved and hierarchical alcazaba ${ }^{13}$.

Through Mármol's work we know of the existence of a public area that was independent from the rest of the alcazaba, where widely used buildings were located, such as a congregational mosque, a square and former madrasa. There, Sultan 'Abdallāh built an alholi $^{14}$ and a munitions dump where gunpowder, rifles and crossbows were made. To the south of this enclosure the "Bib el Tobul" "15 was located, with a market and a street leading from it to the "Cereque" 16 . Passing through the gate, a second enclosure was reached that included the prison for the king's Christian captives, as well as the Dār al-Șinā' or artillery factory, the stables and the guards' and civil servants' quarters. Lastly, a third sector existed, where 'Abdallāh built superb palaces and gardens for himself and his family. Two mexuars for audiences stood between the second and third enclosure, as well as other facilities such as the mint and the customs office ${ }^{17}$.

To this list of buildings we must also add the first mausoleum (darīh) of the Saadian funerary complex (qubūr al-ašrāf), a qubba situated next to the mosque of the Qașba, which has been preserved almost intact. This is where 'Abdallāh buried his father Muhammad alŠaykh, and the place where his remains were put to rest ${ }^{18}$.

\footnotetext{
${ }^{9}$ The process was repeated after the disintegration of the Saadian dynasty, when this facility once again fell into ruin to be later refurbished by the Alawite sultan Muhammad ibn 'Abdallāh (1757-1790) almost a century later, who built a group of palaces to the south of the ruins of the al-Badī' palace. Deverdun, Marrakech des origines $\grave{a}$ 1912 (Rabat: Editions Techniques Nord-Africaines, 1959-1966), pp.510-511.

${ }^{10}$ This plan was drawn by the Trinitarian friar Antonio de Conçeyçao and it accompanied a report kept at the library in El Escorial.

${ }^{11}$ There have been more detailed studies of the alcazaba, carried out especially on the basis of the analysis of the 1585 Portuguese plan. These studies have revealed the material importance of the Saadian alcazaba. Henry Koehler, "La Kasba saadienne de Marrakech, d'après un plan manuscrit de 1585" Hesperis 27 (1940). Deverdun, Marrakech, 384-392. Barrucand, Urbanisme princier in Islam: Meknès et les villes royales islamiques postmédiévales (Paris: Librairie Orientaliste Paul Geuthner, 1985), pp.114-122.Barrucand, "The sadi Qasaba of Marrakesh", Environmental Design: "Urban Fabric"VII, n 1-2 (1989): 18-27.

${ }^{12}$ Leo Africanus, Descripcion, 168-171.

${ }^{13}$ Luis del Mármol Carvajal, Descripción general de África, vol.2, book 3 (Granada, 1573), fol.29-32.

${ }^{14}$ The Spanish terms alholí, alfolí, alhorí derive from the Arabic al-hurī, which translates as granary.

${ }^{15} \mathrm{~B} \overline{\mathrm{a}} \mathrm{b}$ al-T $\mathrm{ubu} \mathrm{l}$ or the Gate of the Drums or Kettledrums.

${ }^{16}$ The name Cereque corresponds to Asarāg, a term with a Berber origin that refers to an open space within the Almohad alcazaba where formal ceremonies and celebrations were carried out. It is similar to the mexuar or mašwar. During the Alawite period it lost its function with the construction of a complex of mexuars to the south of the alcazaba. Deverdun, Marrakech, 222-224 and 387-388. Etimology compiled by Emile Laoust. Emile Laoust, "Contribution à une étude de la toponymie du Haut Atlas", Révue des études islamiques 2 (1939): 220276.

${ }^{17}$ These two mexuars can be identified in the 1585 Portuguese plan, in which they are marked; one of them shows an oratory with a minaret.

${ }^{18}$ Al-Ifrānī, Nozhet-Elhâdi, 56.
} 


\subsection{The refurbishment of the Almohad mosque of the Qașba}

A very large congregational mosque built by Caliph Abu Yūsuf Ya 'qūb al-Manșūr (1184-1199) had always stood in the public area of the alcazaba ever since the Almohad period (Figure 1.3) ${ }^{19}$. It is the most unique, monumental, Almohad mosque of its type. Despite maintaining some of the archetypal traits that can be seen in the Tinmal and Kutubiyya mosques that preceded it, the general proportion of its plan was transformed and the number of courtyards multiplied. This is not all that strange, since this layout was repeated in another mosque built by the same caliph in Rabat. What makes this one in the Qașba of Marrakesh unique are a series of anomalies and irregularities that would not be found in a newly built mosque; therefore, the only explanation for their existence is that this building resulted from the thorough transformation of the Almohad structure ${ }^{20}$. The architectural survey that we have carried out in 2018 have enabled us to verify that a comprehensive renewal of the building was carried out during the Saadian period, something that is easily recognizable in the transversal nave next to the wall of the qibla.

To this we must also add an account by al-Ifrānī (1670-1747) that relates the unforeseen refurbishment of the building carried out by 'Abdallāh as a consequence of an illfated event:

"In the year 981 (1573-74) the gunpowder incident occurred, with the collapse of the large dome (qubba) of al-Manșür's mosque and the cracking of the minaret (sawma 'a). All of this was the result of the scheme of Christian captives who made an underground tunnel and filled it with gunpowder in order to destroy the mosque with all of the people inside on a Friday"21.

Luis de Mármol and Diego de Torres also give an account of this same incident. The former dates it to 1569 and the latter to 1572 ; both years coincide with the reign of Abdallāh ${ }^{22}$. Moreover, an inscription gathered by Deverdun leaves proof of the refurbishment of one of the domes and attributes it to this sultan ${ }^{23}$.

\subsection{The creation and layout of neighborhoods}

Besides recovering the space of power, the Qașba, 'Abdallāh reorganized the medina, a painstaking enterprise since, in some cases, it meant displacing its inhabitants to other parts of the city. The most notable example of this operation is the creation of a Jewish quarter or Mellah, a new neighborhood attached to the Qașba and surrounded by a wall, established to accommodate the entire Jewish population of Marrakesh, which up until then lived dispersed

\footnotetext{
${ }^{19}$ It corresponded with the type of courtesan mosque linked directly with alcazabas or palatial complexes, as seen in Madīnat al-Zahrā', the Alhambra, New Fez and Seville.

${ }^{20}$ Some studies have pointed out the existence of these anomalies and questioned the Almohad origin of the current plan. Basset and Terrasse, Sanctuaires et forteresses almohades (Paris: Larose, 1932), pp. 274-310. Christian Ewert and Jens-Peter Wisshak, "Forschungen zur almohadischen Moschee III: Die Qasba-Moschee in Marrakesch", Madrider Mitteilungen 28 (1987): 187. Dolores Villalba, La senda de los almohades: arquitectura y patrimonio (Granada: Universidad de Granada, 2015), p.170.

${ }^{21}$ Al-Ifrānī, Nozhet-Elhâdi, 51.

${ }^{22}$ Mármol, Descripción, fol.30. Diego de Torres, Relación del origen y suceso de los xarifes y del estado de los reinos de Marruecos, Fez y Tarudante, ed. Mercedes García-Arenal (Madrid: Siglo Veintiuno de España editores, 1980), p.293.

${ }^{23}$ Deverdun, Inscriptions, pp.55-56.
} 
throughout the city. Both Luis de Mármol and Diego de Torres chronicle this intervention and provide information with regards to this new neighborhood ${ }^{24}$. However, the true goal of this operation may have been to isolate the Jewish population in order to avoid conflict, using a solution similar to the one employed in New Fez. There, the Jewish quarter is a walled enclosure controlled by gates and attached to the palatial city, therefore under the protection and control of those in power ${ }^{25}$.

Another example of this is the former leper colony that was once located beyond the Bāb Agmāt gate which, during the Saadian period, may have been moved to the plain next to the Bāb Dukkāla gate (Figure 1.C). We do not know what motivated this decision, but it coincides with the construction of the mausoleum for Abū Ya'qūb Yūsuf ibn 'Alī (Figure 1.11), which can be attributed to sultan 'Abdallāh ${ }^{26}$.

Lastly, we know of the creation of another neighborhood, known as the Riyād alZaytūn (Figure 1.D), built to accommodate the city's newly arrived population. It is located in the area of the medina closest to the Qasba and it is laid out along two long, north-south, commercial streets. Through Mármol we know that sultan 'Abdallāh gave agricultural land in the outskirts of the city to the moriscos that had arrived from Órgiva, Tabernas and other towns of the old Kingdom of Granada, and that they settled next to the alcazaba in a neighborhood known as the Arriat Zeytun"27. This community's role in Marrakesh is of great historical, political and military importance, since 'Abdallāh recruited Andalusians that had settled throughout Morocco and ordered them to move to Marrakesh with the aim of establishing an artillery corps or "Fire Army" (Jayš min al-Nārr) ${ }^{28}$. The moriscos were wellknown at the time for their knowledge of artillery and they brought with them the new warfare techniques that were in use in the Iberian Peninsula ${ }^{29}$.

\subsection{The recovery of agricultural lands and the adduction of water.}

It was precisely 'Abdallāh who, according to al-Fištālī: "conceded iqtā 'ât [to the moriscos] on the western section of the [city's] plain, where they cultivated fields and created orchards (jannāt), some with trees and others without, thus appeasing the nostalgia for their homeland" 30 . This had been described a few years earlier in Mármol's writings, stating that "Abdallāh had brought "a large amount of water" to the city, a ditch that came from Agmāt which served more than fifty mills and watered many orchards "planted by the Andalusian Moors"31.

This "large amount of water" may be identified with the Tassoultant ditch, which has provided water uninterruptedly to the estate of al-Buhayra since its foundation by the

\footnotetext{
${ }^{24}$ Mármol, Descripción, fol.32.Torres, Relación, 295.

${ }^{25}$ Mellah is the usual transcription of the term Mallāh, a name used in Morocco to refer to a Jewish quarter. It was first used in Fez during the Marinid period due to the location of the Jewish quarter in a saline enclave. Encyclopedia of Islam, second edition ed. P.J. Bearman (Leiden: Brill, 2012), Mallāh, ed., H. Zafrani. Para la Mellah de Fez véase: Hicham Rguig, "Quand Fès inventait le Mellah", en Le Maroc médiéval. Un empire de l'Afrique à l'Espagne, eds. Lintz, Yannick and Déléry, Claire (París:Hazan, 2014),pp.452-454.

${ }^{26}$ Deverdun, Marrakech, 378-379. Deverdun, Inscriptions, 42, nº49.

${ }^{27}$ Mármol, Descripción, fol.33.

${ }^{28}$ Mercedes García-Arenal, "Los andalusíes en el ejército sa'dí: un intento de golpe de estado contra Ahmad alMansur al-Dahabi, 1578”, Al-Qantara V (1984): 179 and 186.

${ }^{29}$ Ibid., 177.

${ }^{30}$ 'Abd al- 'Az̄ìz al-Fištālī, Manāhil al-șafā' fì mātir mawālīnā al-šurafā', ed. Abd al-Karim Kurayyim (Rabat: Matbuat wizarat al-Awqaf, 1973), p.42, translated into Spanish by Mercedes García-Arenal in García-Arenal, "Los andalusíes", 179.

${ }^{31}$ Mármol, Descripción, fol.33.
} 
Almohads. We know for a fact that during the Saadian period the estate was restored with the name Rawd al-Masarra, and that the reparation of this ancient channel was crucial for the recovery of the estate and its large reservoir ${ }^{32}$. It is logical to think that this sultan wished to have an agricultural estate that could serve both as a productive space and a place for leisure, as had been the custom in the Western Islamic world since the Umayyad period. Besides the recovery of this ditch, Mármol attributes to 'Abdallāh the construction of khattāara/s, underground channels that captured and brought drinking water to the city of Marrakesh ${ }^{33}$.

\subsection{Cultural and health facilities}

Following the example set by the Marinid sultans, 'Abdallāh also undertook the foundation of institutions at the service of the community. To this end, he built a madrasa and a māristān (hospital).

The most well-known of the two is what is now called the Ibn Yūsuf madrasa, located next to the mosque of Almoravid origins that bears the same name (Figure 1.1 and 1.8). However, in origin it was called al-Madrasa al-Ghālibiyya, in clear reference to its promoter $^{34}$. In general, both Arab and Latin written sources attribute its construction to 'Abdallāh, even though al-Ifrānī states that this sovereign refurbished an older madrasa from the Marinid period. The building has been preserved practically intact and, in fact, it does not show visible signs of different construction phases; instead it responds to a rather predetermined unitary design. It is a colossal building in which ornamental and building solutions from other Marinid madrasas have been employed, even though it differs from these models in the innovative and completely rational design of its floor plan.

As for the māristān, the only testimony we have of its existence is through the words of al-Ifrānī, who includes this building among the works he attributes to 'Abdallāh, indicating that large endowments $(a w q \bar{a} f)$ were set aside for $\mathrm{it}^{35}$. However, not a single physical trace of its existence has reached us. We believe that the hospital must have followed the layout of its Marinid and Nasrid predecessors, along the lines of one that can be found in Granada ${ }^{36}$.

\subsection{Religious facilities}

The buildings for religious uses are some of the most interesting and relevant of 'Abdallāh's project to equip and beautify the city. Even though we do not have sufficient information to fully verify this, among them we could include the Sīdī Yūsuf ibn 'Alì zầwiya (Figure 1.11), an edifice raised outside the Bāb Agmāt gate around the burial space of an ancient ascetic ${ }^{37}$. It is an elegant mausoleum with a square floor plan and central qubba, accompanied by two atriums. Its design and ornamentation are typical of the Saadian period and the epigraphic inscriptions on the marble columns show the name of the sultan.

\footnotetext{
32 Julio Navarro, Fidel Garrido, Iñigo Almela, "The Agdal of Marrakesh (twelfth to twentieth centuries): an agricultural space for caliphs and sultans. Part 1: History", Muqarnas 34 (2017): 30-31.

${ }^{33}$ Mármol, Descripción, fol.33.

${ }^{34}$ Rašīd al- 'Affāqī and Samīr Ayt Ūmgār, Tārīkh Madrasat Ibn Yūsuf bi-Marrākuš (Marrākuš: Āfāq, 2016).

${ }^{35}$ Al-Ifrān̄ì, Nozhet-Elhâdi, 51 .

${ }^{36}$ Acording to Luccioni, the building was ruinous, it had many lugubrious spaces and its maintenance was the responsibility of the makhzan. Joseph Luccioni, Les fondations pieuses "habous" au Maroc: depuis les origines jusqu'a 1956 (Rabat: Imprimerie Royale, 1982), p.101. Deverdun connected the māristān with a series of ruins located in the center of the medina. Later, Raji stated that they had been demolished in the 1960s. Deverdun, Marrakech, 378. Raji Elillah, La Ville, 225.

${ }^{37}$ Even though architecturally speaking it may be considered a Saadian building, we cannot state that it belongs to this period because we suspect that the columns and other marble elements come from another building.
} 
The other examples of religious architecture that were part of 'Abdallāh's project for the urban renewal of Marrakesh are two complexes with mosques as their central function. They will be described in more detail in the following section, as they are the main theme of this article.

\section{Two religious complexes in Marrakesh}

These two architectural complexes have mosques at their core and they comprise several buildings. Some of these buildings were designed for uses that support the practice of religion, such as ablution pavilions, madrasas, Koranic schools and libraries, and others have more secular programs, such as shops, baths or fountains. These ensembles have a planned layout and the buildings all belong to a unitary project, the construction of which played an important role in the formation, expansion and restructuring of entire neighborhoods, while also generating urban life in these areas ${ }^{38}$.

In fact, this telling relationship between architecture and urbanism, or rather, between these complexes and their surrounding urban tissue, justifies the need to carry out an analysis of the urban context before addressing the description of the two complexes. With this objective, we have drawn up plans of their settings. The analysis of these plans has revealed the existence of a hierarchical order in the layout of the streets and enabled us to identify anomalies that show some of the transformations that may have taken place due to the construction of the complexes ${ }^{39}$. Despite the difficulties of producing plans that could represent the layout of the city during the Saadian period-due to the imprecision of written sources, the lack of an archaeological register and the absence of detailed plans of the city up until practically our days - we have tried, aware of these limitations, to depict the urban landscape of the time. To create these hypothetical plans, we have based our work on maps and plans from the nineteenth and twentieth centuries ${ }^{40}$.

Likewise, it is even harder to know what the site of these complexes was like before their construction, since only archaeological excavations could provide enough information about previous phases of land occupation and abandonment. Given all of this, the urban analysis we have carried out aims at providing some information about the evolution of the two enclaves during the Saadian period and at reconstructing the process by which each religious complex was inserted into its corresponding urban tissue. First, the elements that may have preexisted before the construction of each complex have been identified. Then, this state has been compared with the layout of each complex, with the intention of showing incompatibilities and the alterations that were introduced in order to insert the complexes into their respective sites. Finally, features that appeared in each area after the construction of the mosques and their annexes have been identified.

\footnotetext{
${ }^{38}$ Mosques greatly influence the layout and structure of neighborhoods due to their social and political importance in the organization of cities and settlements. Carmen Trillo, "Mezquitas en al-Andalus: un espacio entre las comunidades y el poder", Studia Historica. Historia Medieval 29 (2011): 73-98.

${ }^{39}$ To draw these plans we have used the photogrametric plan produced by the Ministerio de Interior, Dirección de Urbanismo, de Ordenación del Territorio y Medio Ambiente in 1987. In order to go further back in time, we have used the 1917 aerial photograph taken by the French army, which is preserved by the Inspection des Monuments de Marrakech.

${ }^{40}$ The main sources used have been the Washington plan from 1830, the Lambert plan from 1867 and the Larras plan from 1899. The process by which the medina of Marrakesh became increasingly and chaotically denser did not begin until the mid-twentieth century, so even the aerial photograph from as late 1917 provides an approximate image of what the cityscape must have been like in the sixteenth and seventeenth centuries. This photograph shows large expanses of cultivated areas, abandoned lots and neighborhoods clustering along the main roads.
} 


\subsection{The al-Muwāssīn complex}

\section{Dating}

In written sources, this mosque is referred to as Jāmi ‘ al-Ašrāf, Jāmi‘ al-Šurafā' or Jāmi' al-Muwāssīn. The latter is its current name and that of the neighborhood where it is located $^{41}$. It seems like the site chosen for its construction was part of the former Jewish quarter of the medina and that the mosque occupied what might have been its cemetery. Two different sources provide information to this regard. On the one hand, the testimony of Luis de Mármol tells us that the Jewish quarter was "in the middle of the city", before sultan 'Abdallāh moved it next to the Qașba ${ }^{42}$. On the other, there is al-Ifrānī's account from the Alawite period; in his work Nuzhat al-hâadi, he mentions the existence of an old Jewish cemetery on the site of the mosque.

"In the year 970 (1562-1563) Mawlāy'Abdallāh built the Mosque of the Shareefs (Jāmi 'al-Ašrāf) and the siqāya next to said mosque, at the epicenter of the medina, in al-Muwāssīn [...]. The devout abstained from praying at the Mosque of the

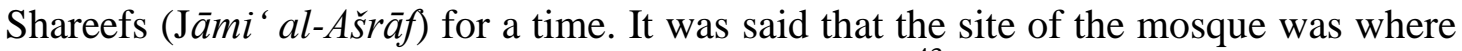
the Jewish cemetery once stood (maqbara li-l-yahūd)" ${ }^{\text {"43 }}$.

This fragment is the first time the Mosque of the Shareefs is connected with the toponym of al-Muwāssīn. It also provides information regarding the date of the construction of the religious complex and the name of the sultan who promoted the works, the same sultan who, according to Mármol, moved the Jewish quarter to the south of the medina.

With this information we can attempt to reconstruct the sequence of events, revealing how 'Abdallāh's initiative may have had two objectives. The first, as mentioned, was to gather the entire Jewish population into a single walled-in enclosure in the vicinity of the qassba and, the second was to free up space in a valuable site of the city located at the center of the medina.

Both the chronology and the authorship of the construction can be confirmed thanks to the discreet inscription that Raji Elillah identified on the steel bolt (zakrūm) of the main door of the mosque.

"Mawlāy'Abdallāh built the Mosque of the Shareefs (Jāmi 'al-Šsurafā') in the year 979 (1571-1572) in the city of Marrakesh"44.

This congregational mosque was an important place of worship and became a prestigious center of religious studies ${ }^{45}$.

\footnotetext{
${ }^{41}$ There are several hypotheses regarding the origin of this toponym. However, in our opinion, the most plausible one derives from the fact that the cutler trade established itself in this area. From the root $m \bar{a} s$, to shave, derives mawās (pl. mūsayāt, amwās), knife, and from there mawwāsī, cutler or knife maker, the plural of which is mawwāsiyyin. Whether or not this term can be considered the origin of the name, and since we are unable to clearly state such a fact, we have decided to use the transcription al-Muwāssīn, therefore remaining faithful to the way it is currently written, without vocalizing the present tense in written sources, and maintaining its current vocalization with a "u" in the first syllable and the pronunciation of a double "s".

${ }^{42}$ Mármol, Descripción, fol. 32.

${ }^{43}$ Al-Ifrān̄i, Nozhet-Elhâdi, 51 and 53.

${ }^{44}$ Given its location in a building fixture, we can interpret that this date corresponds approximately to the time when the construction of the mosque was finalized. Raji Elillah, La Ville, 51. There is a difference of nine years with respect to the date provided by al-Ifrān̄i, however both fall within the reign of 'Abdallāh al-Ghālib.
} 


\section{Urban context}

In all probability, this central sector of the medina (Figure 1.6 and 2) had been occupied ever since the Almohad period, even though the city's decline during the fifteenth century must have brought about a fall in its population and the shrinking of its inhabited area. In any case, after the expropriation of the Jewish quarter, the foundation of this complex in the sixteenth century led to an urban revival.

On the basis of the system of main streets and alleys, we can visualize the overall layout that had structured the neighborhood since its origins (Figure 2). Two very clear main axes meet and cross at this point. The first runs from north to south and connects the central neighborhood of Ibn Yūsuf with the Jemaa el-Fna square. The second has a more winding layout with two distinct sections. The most regular part corresponds to Sīdī al-Yamāni street and it comes from the western end of the medina. The second section includes the alMuwāssīn square itself and commercial streets that fork off to the east. These two main arteries are known as Ṭuwwālat al-Muwāssīn and Ṭuwwālat Sīdī al-Yamān̄̄ ${ }^{46}$.

A series of alleys (darbs) branch off from these two main streets. Some may be the remains of the original layout of this sector, since they are orthogonal to the arteries, at least along their first stretches. This is the case of Darb 'Azzūz, Darb Chorfa al-kbir (al-Šurafā' alKabīir) and Darb Lagnaiz ${ }^{47}$. Another set of alleys with very irregular layouts correspond to periods when the urban tissue densified and became hypertrophied, as is the case of Darb Chorfa al-Sgir (al-Šurafā' al-Șagīr).

If we consider that the two main arteries and the set of orthogonal alleys predate the Saadian period, we can detect and interpret some fossilized scars in the urban tissue caused by the insertion of the complex. These irregular traces are due to the expropriation processes and razing (Figure $2 \mathrm{~B}$ and $2 \mathrm{C}$ ) of the site in preparation for the construction complex ${ }^{48}$. The insertion of the mosque was especially significant due to its large floor plan and its predetermined orientation following religious precepts. In this way, we can observe how, in our opinion, it "bit" into some of the pre-existing alignments (Figure 2C). This is the case of the main north-south street now occupied by the minaret and part of the mosque ${ }^{49}$. Here, the interruption of the street also meant rerouting the flow around the northwestern corner of the mosque. In the same way, the directrix of the Lagnaiz alley was cut by the retreat room and the southwestern corner of the building, which entailed severing away part of the houses located to the south of the alley in order to change the trajectory of the alleyway. Lastly, the northern and eastern sections that delimit the public square completely break away from the irregular and oblique layout of the plots to which they are attached.

\footnotetext{
${ }^{45}$ We know of the existence of several scholars who worked at the mosque or who frequented it to offer exegesis

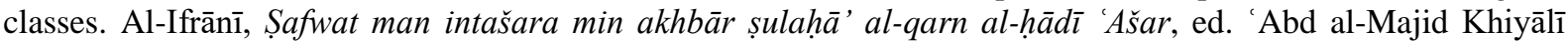
(Casablanca: Markaz al-Turāt al-Taqāfa, 2004), pp. 99, 116 \& 347.

${ }^{46}$ Raji Elillah, La Ville, 243. Nowadays, some streets have kept the term tuwwāla, while others have substituted it with Rue.

47 The name of this alley comes from the term al-janā'iz, (funerals). The funeral space behind the qibla may have been located in one of the back rooms attached to the library, as was customary. A clear example of this is the al-Qarawiyyin mosque, which even has a door with that name.

${ }^{48}$ Thanks to written and archaeological sources we know that the construction and extensions of mosques often involved the expropriation of houses. Such is the case of the Great Mosques of al-Qarawiyyīn, Kutubiyya and Seville.

${ }^{49}$ In this area there is a plot with a trapezoidal plan that has been divided at an angle.
} 
Despite these operations to adapt the Saadian complex to the preexisting structures, we think that the main reason for choosing this site was its optimal location and connectivity with the urban tissue of the area, regardless of the scarce space available for its construction. If it had not been for this, the complex could have been built elsewhere, on a site where there were fewer constraints.

For this new Saadian construction, the doors of the mosque were located at points where the volume of the building intersects with the layout of the preexisting streets, thus ensuring its relationship with public space. Following this same logic, the square is strategically situated next to where the two arteries cross and, in fact, it is crossed longitudinally by one of them. On their part, the annexes that are independent from the mosque (the trough-fountain or siquaya, the ablutions pavilion or míd $\bar{a}^{\prime} a$ and the bathhouse or hammām) did not require a specific orientation, therefore the criteria for their setting was more flexible ${ }^{50}$. In fact, the hammām had to adapt to its surroundings, since it is set back with respect to the other two annexes, as if it was meant to respect the buildings located to the north of it. This solution entailed generating an intricate access into the bathhouse.

Lastly, in order for this complex to function properly, a constant water supply had to be guaranteed, possibly leading to the construction of the 'Ayn al-Muwāssīn khattāara. This hydraulic infrastructure supplies water to the western sector of the medina and functions as an element that articulates the neighborhoods ${ }^{51}$. Its main goal was to supply water to the religious complex and it was run, at least in part, by the hubus, who was also in charge of its maintenance ${ }^{52}$. As we have seen, sultan 'Abdallāh undertook the construction of a series of important waterworks to ensure the city's water supply; this khatțāra was probably one of them.

After the complex opened, all sorts of other activities were attracted to the area; commerce along the surrounding streets grew and new residents arrived, leading to the revitalization of the neighborhood ${ }^{53}$. In fact, this natural densification process brought about the occupation of empty plots and the invasion with shops and houses of the residual spaces that remained between the northern and western facades of the mosque and the main arteries (Figure 2).

\section{General description of the complex}

The religious complex comprises a group of buildings of which the mosque, due to its size and function, is the main feature, with the remaining facilities organized around it (Figure 3 ). As we have suggested above, the complex has two parts, each of which follows its own orientation. On the one hand, the mosque and a series of annexes attached to it are perfectly oriented towards Mecca, following a layout that is unavoidably extraneous to the preexisting tissue. On the other, the square and the independent annexes (the ablutions pavilion, the fountain-trough building, the bathhouse and the Koranic school), make up a compact ensemble to the northeast and are oriented differently.

\footnotetext{
${ }^{50}$ In this sense, it seems like these three annexes followed the orientation of the lots located to the east of the hammām.

${ }^{51}$ Luccioni, Les fondations, 108.

${ }^{52}$ The khattāara/swere usually owned by the hubus or the Makhzan. Luccioni, Les fondations, 108.

${ }^{53}$ Some of the new residents were high dignitaries and renowned people such as Abū al-Hasan 'Alī ibn Sulaymān al-Tamilī, wālīof sultan 'Abdallāh al-Ghālib. Al-Ifrānī, Nozhet-Elhâdi, 170. And also Muhammad ibn Yūsuf al-Tadgī (m. 1600), who lived on Darb 'Ubayd Allāh.Aḥmad ibn al-Qāḍ̄i, Durrat al-ḥijāl fi asmā'i alrijāl, ed. I. S. Alūš, (Rabat: al-Maṭba'a al-Jadīda, 1934), vol.I, p.232.
} 
For the most part, these annexes have water-related uses as their main program, therefore grouping them together made sense to optimize the water supply and sewage infrastructures. These buildings are closely interconnected, and they relate to the mosque by means of two public spaces, which can also be considered part of the complex. The first is the Alley of the Hammām that separates these facilities from the mosque along the eastern facade of the latter. The second is the square to the north, where most of the accesses and communications of the complex are concentrated. In fact, this open area is one of the most unique spaces of the city, since this type of square is uncommon in Marrakesh (Figure 6).

The design of the mosque is based on a traditional rectangular-plan layout divided into two parts, one accommodating the prayer space (harām) and the other the courtyard (sahn). The latter is square and has three porticoed galleries (riwāq pl. arwiqa). The prayer hall is divided into two sectors by means of a transversal portico. The southern sector consists of a nave set parallel to the wall of the qibla, while the northern sector is a large space subdivided into seven naves (bläta) set perpendicular to the qibla. The hierarchical organization of the prayer hall is based on the traditional T-plan layout of Almohad mosques, in which the central and transversal nave stand out due to their spatiality and ornamentation ${ }^{54}$. At the point where these naves intersect, a space with a square plan is generated constituting the focal point of the prayer hall, that is, the maqșüra, or the reserved space across from the mihrāb. These elements - the main nave, the maqșüra, and the mihrāb-mark the main longitudinal axis of the building, which is completed with the door set at the center of the northern wall and its corresponding qubba. Following the Almohad model, the transversal nave located next to the qibla is covered by three domes with muqarbas, one at the center and two at either end. The central one is the most important as it highlights the space of the maqșurra. The rest of the naves are covered by wooden ceilings. Lastly, on the exterior, the building presents two facades to the west and north (Figure 4), with narrow porticoes attached to the perimeter walls and subdivided into a sequence of modules ${ }^{55}$.

As for the program attached to the mosque, the most outstanding is the tower of the minaret (sawma'a) due to its size and unfinished state (Figure 7A). If it had been concluded, it would have been one of the tallest minarets in Marrakesh ${ }^{56}$. The other annexes are the retreat room (bayt al-i'tikäf), attached to the southern end of the western facade, and the library (khizāna), located behind the wall of the qibla ${ }^{57}$. Next to it, the service rooms for the imam

\footnotetext{
54 Basset and Terrasse, Sanctuaires et forteresses almohades, pp. 46-56; Ewert, "The Mosque of Tinmal (Morocco) and Some New Aspects of Islamic Architectural Typology", Proceedings of the British Academy 72 (1986): 136-141; Alfonso Jiménez Martín, "Las mezquitas", Sevilla almohade, coord. Magdalena Valor Piechotta and Ahmed Tahiri (Sevilla: Fundación de las Tres Culturas, 1999), pp.99-101; Alfonso Jiménez Martín, "Notas sobre la mezquita mayor de la Sevilla almohade", Artigrama 22 (2007): 138-139; Khiara and Leonetti, "Tinmal et la construction de la légitimité mu'minide", pp. 281-284; Elkhammar, "Contribution à l'étude des mosques almohades", en Le Maroc médiéval. Un empire de l'Afrique à l'Espagne, eds. Lintz, Yannick and Déléry, Claire, París, Hazan, 2014, pp. 320-323.

55 The function of these modules is unknown, since at a structural level they are not necessary to add resistance to the wall of the mosque. However, this type of facade can be seen in several Almohad mosques, such as the first and second Kutubiyya mosques, the mosque of the Qașba and the mosque of Rabat. With these precedents, we suspect that this design solution had been present in Marrakesh since the Almohad period.

${ }^{56}$ In fact, this minaret would have only been surpased by the ones at the Kutubiyya and the Qașba mosques. Interestingly, the plan of the al-Muwāssīn minaret is almost identical to the one at the Qașba mosque, which was probably refurbished during the same period as the construction of the al-Muwāssīn complex.

${ }^{57}$ As the founder of the Maliki School expressed in his work (al-Muwatta' '), spiritual retreats or i'tikāf had to take place within the mosques, something that the Quran already stated. Susana Calvo, Las mezquitas de alAndalus (Almería: Fundación Ibn Tufayl de Estudios Árabes, 2014), pp. 250-251.
} 
and the khatib are set (bayt al-khațib) as well as the former funerary mosque (masjid aljanā'iz $)^{58}$.

The rest of the annexes as well as the square are independent from the mosque (Figures 3, 4 and 5). The first group of annexes comprises a series of facilities and spaces that have a direct relationship with the street, including the aforementioned public square, a row of shops on its northern side, a large gate that leads into the souk to the east, and the troughfountain to the south. The latter is a structure composed of three vaulted modules and includes a richly decorated fountain ${ }^{59}$. The second annex, the ablutions pavilion, is attached to the back of the drinking trough building, providing a fundamental service to those who attend prayers in the mosque. It has a rectangular courtyard surrounded by four galleries with latrines, all presided by a central pavilion (Figures 5 and 7B). This pavilion is covered with a timber roof structure and it protects a large water basin with a perimeter channel where the most basic ablutions can be carried out. The third annex is the bathhouse, an important establishment within the complex thanks to the revenue it brings in. It is an elongated construction with a rectangular floor plan set between the ablutions pavilion and other buildings, in such a way that it can only be accessed from the square by means of an angled passageway. It follows the traditional Andalusian-Maghrebi layout, although it was divided at a much later date in order to provide its services to both sexes simultaneously.

As for the house located between the bathhouse, the mị̂a' $a$ and the mosque, we suspect that, at some point, when it was extended, sections of public space were invaded. On the one hand, the house occupied an old alleyway that ran along the south of the mis $d \bar{a}$ 'a connecting the Alley of the Hammām with the passage into the bathhouse perpendicularly. And on the other, it also occupied, by creating a covered passageway, the narrow alley that once separated the house itself from the bath. Therefore, before these changes, the original layout may have contemplated various ways of accessing the bathhouse.

Lastly, other facilities were located on the first floors of these buildings due to spatial contingencies. This is the case of the Koranic school (kuttāb) located in the vicinity of the eastern door of the mosque, as well as a group of houses situated above the door of the $m \bar{\imath} \underline{a} \bar{a}^{\prime} a$. Both were built over the Alley of the Hammām. Besides this, another covered passageway was built to accommodate the muwaqqit next to the western facade of the mosque, that is, above one of the main streets ${ }^{60}$.

\footnotetext{
${ }^{58}$ Henri Terrasse, La Mosquee al-Qaraouiyin a Fes (Paris: Librairie C. Klincksieck, 1968), pp. 21-22. Maribel Fierro, "El espacio de los muertos: fetuas andalusíes sobre tumbas y cementerios", in L'urbanisme dans l'occident musulman au moyen âge: aspects juridiques, ed. Maribel Fierro, Jean-Pierre van Staëvel and Patrice Cressier (Madrid: Casa de Velázquez and CSIC, 2000), pp.153-189.Calvo, Las mezquitas de al-Andalus, pp. 167-169.

${ }^{59}$ The fountain-trough copies a local model present in the Almoravid remains of Ibn Yūsuf. The Saadians reused this design and developed it. Deverdun, Marrakech, 415-416. Jacques Meunié, Henri Terrasse and Gaston Deverdun, Nouvelle recherches arquéologiques a Marrakech (Paris: Arts et metiers graphiques, 1957), pp.6-20. ${ }^{60}$ The muwaqqit is someone who works for the mosque in charge of establishing prayer times and issues related with the Islamic calendar.
} 


\subsection{The Bāb Dukkāla complex $^{61}$}

\section{Dating}

Despite the contradictory and imprecise statements found in the written sources we have consulted regarding dates of the construction of this complex, most coincide in attributing it and the various donations involved in the process to the mother of sultan Ahmad al-Manșūr (1578-1603). Marçais and Deverdun date it to 1557-58 (falling within the period of 'Abdallāh al-Ghālib's rule), based on dates provided by al-Ifrānī:

"And his [Aḥmad al-Manșūr's] mother al-hurra Mas'ūda daughter of the splendid Šaykh Abū al-'Abbās Aḥmad ibn 'Abdallāh al-Wazkīî̀ al-Warzazātī was a benefactor who wished to build monuments (mafākhir) and to do good. He [Ibn al-Qāẹī] said in al-Monteqà ${ }^{62}$ that she built the mosque in the neighborhood of Bāb Dukkāla (masjid al-jāmi' bi-hawmat Bāb Dukkāla) within the medina of Marrakesh and that she established a charitable fund (awqāf). That was in the year $965(1557-1558){ }^{\prime 63}$.

Ibn al-Qāḍ̄, in his work al-Muntaqà al-maqșūr, also states that the construction of the building and its annexes is connected with al-Manșūr's mother:

"Among what she ordered to build is the mosque (al-masjid) that she constructed in Bāb Dukkāla in Marrākuš. A large mosque (masjid 'aẓim) where congregational prayer takes place (al-jumu'a). She endowed it (habbasat) with a generous charitable trust (waqf(an) 'azim(an))".

An attached tahbiss follows, dated in the month of muharram of the year 995 (1585), detailing these donations: shops, houses, water sources and cultivated land ${ }^{64}$. This document also states that rights and benefits of these donations must be destined, in perpetuity, to the maintenance of the mosque, the salaries of the imams, mullahs, muezzins and other employees, as well as to finish its construction ${ }^{65}$.

However, Raji Elillah found a fiqh book bequeathed to the al-Hurra mosque by 'Abdallāh al-Ghālib in 1570-71/978, which, we interpret, establishes the construction of the mosque at an earlier date ${ }^{66}$. The record of this donation and the tahbis documented by Ibn alQāḍi use the term al-Hurra in allusion to the mosque, a clear reference to a woman belonging to the family of the sultan ${ }^{67}$. However, in the fifteen years that span between both documents important political changes took place. This means that the project was probably begun under

\footnotetext{
${ }^{61}$ About this complex, we have recently published a detailed study. Íñigo Almela, "El conjunto religioso de Bāb Dukkāla: levantamiento y análisis", Al-Qantara 38, n² (2017): 333-386.

${ }^{62}$ Aḥmad Ibn al-Qāḍ̂̄, Al-muntaqà al-maqșūr ‘alà ma'âtīr al-khalīfa al-Manșūr, ed. Muhammad Razzūq (Rabat: Maktabat al-ma'ārif, 1986), p.257.

${ }^{63}$ Al-Ifrānī, Nozhet-Elhâdi, p.79.

${ }^{64}$ Ibn al-Qāộ, Al-muntaqà al-maqșūr, 257-267.This date also appears in the version given by al-Nāșirīin the nineteenth century. Aḥmad al-Nāṣirī, Kitāb al-Istiqșā li-akhbār al-Magrib al-Aqsà, ed. Ja'far al-Nāṣirī and Muhammad al- Nāṣirī (Casablanca: Dar al-Kitab, 1997), t.V, pp.117-118.

${ }^{65}$ According to Deverdun, this disparity in the dates can be due to the fact that construction began in 1557-58 and finished in 1586. Deverdun, Marrakech, 413.

${ }^{66}$ This is the Tahd̄īb al-mudawwana of Khalaf ibn Abī al-Qāsim Abū Sa‘̄̄d al-Azd̄̄, known as Barādi‘̄i. Raji Elillah, La Ville, 109.

${ }^{67}$ The title al-hurra is used for women who belonged to the sultan's family and who enjoy a certain freedom. Bárbara Boloix, Las sultanas de la Alhambra: las grandes desconocidas del reino nazarí de Granada (siglos XIII-XV) (Granada: Patronato de la Alhambra y del Generalife: Comares, 2013), p.328.
} 
'Abdallāh's rule and that it was finished later, around the time when the second endowment was recorded, the year 1585, in which the need to finish the construction work is mentioned ${ }^{68}$.

\section{Urban context}

The Bāb Dukkāla district (Figures 1.7 and 8) comprised a single neighborhood that shared the same name as the complex until the end of the nineteenth century. The heart of the original settlement dates back to the Almohad period at least ${ }^{69}$. With regards to this, an account exists about the grammarian Mūsà Yalbaht narrating how, during the rule of the caliph al-Manșūr, he was forced to give classes in a mosque near Bāb Agmāt, because Bāb Dukkāla was too small ${ }^{70}$. However, at the beginning of the Saadian period and as a result of the crisis suffered by the city during the fifteenth century, this area was probably comprised of abandoned lots. The construction of the mosque and its annexes, along with new waterworks, as Ibn al-Qādī pointed out, revitalized this section of the city ${ }^{71}$. The project integrated the western sector of the medina into the new urban dynamic, and therefore, new residential buildings and commercial facilities flourished. We have no information regarding the actual expanse of this neighborhood, but it probably did not occupy much of the area beyond the immediate surroundings of the complex, given that in the Lambert Plan from 1868 it appears like an island surrounded by open spaces ${ }^{72}$. Commercial activities sprung along the main arteries and they became especially present in the vicinity to the mosque, as historical photographs show and we can still see today.

The name given to this architectural complex as well as to the neighborhood at the heart of which it is located, derives from its setting at the merging point of two important roads that lead to the Dukkāla gate, which dates back to the Almoravid period and is situated at the northwestern-most point of the medina. The first road is called Tarīq Sìdī 'Abd al'Azīz, and it comes from the part of the historic center created by the Almoravids around what is now the Ibn Yūsuf mosque. The second road is what is now Šāri' Fātima al-Zahrā' Street, which comes from the area established by the Almohads as the center of the city around the Kutubiyya mosque. These two arteries are the oldest parts of the layout of this neighborhood, since they correspond to the ancient paths that led from the two aforementioned historic congregational mosques to the Bāb Dukkāla gate.

Without a doubt, the site for this complex was also chosen with the intention of providing this prime location with new buildings in order to revitalize this sector of the city. The availability of open spaces within the triangular area delimited by the two arteries along with the low density of its surroundings made it possible to conceive a rational plan for the project. This orthogonal layout with buildings set parallel to one another was determined by the orientation of the wall of the qibla and it did not take into account the exiting alignments of the main streets. From this we can deduce that, in all probability, there were no pre-existing

\footnotetext{
${ }^{68} \mathrm{Ahmad}$ al-Manșūr's mother is the only woman that is mentioned as the promoter of this work in the written sources that have been consulted. Therefore, if she was the sole promoter of the mosque, she must have enjoyed immunity and a very favorable financial status during the reign of her stepson 'Abdallāh and the exile of her son Aḥmad al-Manșūr.

${ }^{69}$ The medina of Marrakesh was administratively organized into districts ('alam), each of which, in turn, comprised one or more neighborhoods (hawma).

${ }^{70}$ Ibn 'Abd al-Malik al-Marrakušī, al-Dַaylwa-l-Takmila li-kitābay al-Mawșūlwa-l-Șila, ed. Muhammad Ibn Šarīfa and Iḥsān 'Abbās (Beirut-Rabat: Dār al-Ṭaqāfa, 1964-1984), vol. VIII, p.249. Raji, La Ville, 245-247.

${ }^{71}$ Ibn al-Qāḍ̄̄, Al-Muntaqà al-maqșūr, 258-259.

72 The neighborhood was surrounded by many enclosed orchards known as 'arșa(t), a term that appears widely in toponyms of the area.
} 
permanent buildings along those sections of the main streets before the Saadian intervention. This made it easier to change the pre-existing street layout enabling more freedom to establish the configuration of the project. Šări' Fātima al-Zahrā' was displaced to the west, creating a large open space, and the street continued along the sides of the madrasa, an annex attached to the northwestern corner of the mosque. In the same way, the facade of the fountain-trough building, which opens onto Țarīq Sīdī 'Abd al-'Azīz, realigned the street along that section producing a small rectangular square in front of it. Lastly, the traces of a preexisting element in the urban tissue to the southeast of the complex seem to influence the layout of the service quarters of the mosque, the hammām as well as other buildings that do not belong to the intervention; they all adapt to an alignment that may correspond with a secondary street that could have existed at this crossroads.

The complex was the origin of a new neighborhood, so the residential tissue we now see probably appeared after its construction. However, an analysis of historical plans and of the current property lines shows that this densification process was never very intense. At least this is what can be deduced from the open area that has remained as such to the west of the mosque, and the scarce fragmentation of the plots.

\section{General description of the complex}

The Bāb Dukkāla complex comprises a group of buildings organized into a series of blocks that are structured by two inner streets (Figures 9 and 12). The difference with the alMuwāssīn complex resides in the orthogonal layout determined by the orientation shared by all of its buildings, those dedicated to religious uses and those that have other functions. Of them all, the congregational mosque stands out once again as the main feature of the complex. Some annexes are attached directly to it: the madrasa, the library, the retreat hall and the funerary mosque. In this case, the minaret is not attached to the outside of the mosque, it is inserted within the perimeter of the building.

A freestanding block is located to the north of the mosque, where the ablutions pavilion, the fountain-trough building and a row of shops are located. Two secondary perpendicular streets separate this block from the rest of the complex, one runs along the eastern facade of the mosque and the other along the facades of a group of buildings located to the south, among which the bathhouse stands.

The complex is perfectly connected to the main arteries at several points. On the one hand, the secondary streets generated by the Saadian project connect the two main arteries providing an alternative route while also giving access to the various annexes and leading to the eastern door of the mosque (Figure 12). In fact, this door is located on the axis of one of the two secondary streets and is visible from Sīdī 'Abd al-'Azīz Street. On the other hand, the mosque opens onto Bāb Dukkāla Street by means of its main northern door (Figure 10) and onto Fătima al-Zahrā' Street thanks to the western door. Lastly, the best example of the clarity of these connections is the facade of the fountain-trough building, which gives shape to a square making the most of the widening of Sīdī 'Abd al-'Azīz Street in that section.

The Bāb Dukkāla mosque has the same layout as the one at the al-Muwāssīn complex, with the same number of naves set perpendicular to the qibla and the same square courtyard with five openings on each side. However, in this case the design is somewhat more intricate, since it incorporates new elements to confer it an identity of its own. The prayer hall is divided into three parts by two inner porticoes that generate two transversal naves, situated to 
the north and to the south respectively. In this way, the resulting space between them accommodates the battery of seven naves set perpendicular to the qibla.

The size of the spaces and the distribution of the decor reveals a hierarchy of spaces based, once again, on the Almohad T-plan. However, in the section of the prayer hall another scheme is employed. This can be seen in the roofs over the main axes of the hall (the central nave, the two lateral naves and the two transversal naves) and in the six nodules that form where they intersect. These six nodules are crowned by domes with muqarbas, while the naves are covered with timber roofs (Figure 11). In this way, the main areas of the prayer hall (maqsüra, 'anza $a^{73}$ and doors) are linked together and the volume maintains its symmetry. In fact, in order to maintain this solution throughout the building, it is also extended to the northern bay, which is likewise covered with two domes, one at the center and another at the northwestern corner. Here, the symmetry of the scheme is broken by placing the minaret at the northeastern end of the nave. However, some irregularities we have detected in this section of the building lead us to think that the minaret belongs to a later phase and that, therefore, this corner may have had another nodule and another dome $\mathrm{e}^{74}$.

On the exterior of the buildings, the low density of the neighborhood has allowed most of the public space to remain unoccupied and, therefore, most of the facades of the mosque are visible. The eastern half of the northern facade includes a false portico with three arches, a solution that in the original design might have also been conceived for the eastern wall of the mosque ${ }^{75}$.

As for the annexes attached to the mosque, most of them have suffered profound changes or have even been segregated altogether from the complex. The madrasa was demolished and on its site a Koranic school was built, while the library and the funerary quarters behind the wall of the qibla have been occupied by a private home. The only space that remains intact is the retreat room. In contrast, the annexes that stand independently from the mosque have been preserved in a better state. However, we lack enough information to establish whether the complex included any other buildings at some point ${ }^{76}$. The fountaintrough building and the ablutions pavilion follow the same model as the one we have described at the al-Muwāssīn complex; they have the same design and the same conjoined layout (Figures 9 and 12). A row of shops is attached to the southeast of these facilities, but their relationship with the rest of the complex is unknown to us. The bathhouse also reproduces the same spatial sequence as the one at al-Muwāssīn, but in this case its original organization has been preserved. As a unique feature, this building has two independent accesses, one per sex, despite its use following alternate schedules. Both accesses are integrated into a gate located on the northern facade.

\footnotetext{
73 'Anaza or 'anza is a term that is still used in Morocco to refer to a structure situated in the central opening leading from the courtyard into the prayer hall. In this way, it is an external mihräb that serves as a reference point for those who pray in the courtyard. It can be a simple detail in the pavement, a wood structure closing off the opening or even both at the same time. In the case of Bāb Dukkāla, it is a mark in the pavement and a modern door that probably replaced an older one. Miles, G.C., "Anaza" in Encyclopedia of Islam. Elkhammar, "Le mobilier des mosquées médiévales du Maroc d'après les sources textuelles", Al-Andalus-Magreb 13 (2006), pp. 79-94.

74 The identification of structures that may correspond to a second phase of construction coincides with the historical analysis that establishes that work on the complex was resumed by al-Manșūr's mother.

${ }^{75}$ We suggest this hypothesis on the basis of the buttress located on the northeastern corner of the Mosque. This structure is part of the openings of the northern facade and the base of an arch that would have been attached to the eastern wall of the mosque.

${ }^{76}$ We know of the existence of a kuttāb located next to the fountain. However, given its aspect in historical photographs, it looks like an addition from a later date.
} 


\section{$\underline{\text { 5. Architectural references }}$}

Taking into account the function of these buildings and the role they play in the city, we can state that they are, in fact, social and religious complexes, in the same way similar examples in other parts of the Islamic world have been considered ${ }^{77}$. This premise enables us to better understand their use, since not all of the buildings that are part of the complexes have purely religious functions. Likewise, it is important to study their origins and ownership, since all of these buildings are part of a waqf or a hubs, that is, a charitable donation. However, it is important to differentiate between the two types of facilities that make up the complexes. On the one hand, there are the unproductive assets, the possession of which entails expenses due to their maintenance costs, as is the case of the mosque. On the other, there are the productive assets, establishments that, given their function or the possibility of renting them out, generate benefits, such as the shops or the hammām ${ }^{78}$. These two types of assets go hand in hand, because without the latter, the former would not be able to exist.

With regards to the Maghreb and al-Andalus, the existence of $m \bar{i} d \bar{a} ' a / \mathrm{s}$ and $h a m m \bar{a} m / \mathrm{s}$ in the vicinity of the mosques has been well documented since the Umayyad period, while madrasa/s have been present in their environs since the beginning in the fourteenth century. However, of all these facilities, the mì $\bar{a} \bar{a}^{\prime} a$ is the most common annex given the essential service it provides ${ }^{79}$. The most outstanding example of this is the Almoravid qubba of Marrakesh, the central pavilion of an ancient mị $\bar{a}^{\prime} a$ that was associated with the Ali ibn Yūsuf mosque. Also important are earlier examples such as the mī $\bar{a} \bar{a}^{\prime} a$ of Almanzor in the Great Mosque of Córdoba ${ }^{80}$. However, the clearest and most direct geographical precedents of the mosque-mī $\bar{a}^{\prime}$ ' $a$ binomial are Marinid complexes, concentrated especially in the area around Fez and other towns in northern Morocco, as well as those in the Algerian region of Tlemcen ${ }^{81}$. Among the mosques built by the Marinids there are numerous cases in which a $m \bar{\imath} \dot{\bar{a}} \bar{a}^{\prime} a$ and minaret are constantly associated with a mosque, while annexes such as libraries, madrasa/s, Koranic schools, funerary mosques or mausoleums appear more sporadically.

At the Abū al-Hasan and al-Zahr mosques in $\mathrm{Fez}^{82}$, we can observe how the mị $\bar{d} \bar{a}$ ' $a$ is juxtaposed to the mosque creating an internal connection between both ${ }^{83}$, while in examples

\footnotetext{
${ }^{77}$ Gülru Necipoğlu, “The Süleymaniye Complex in Istanbul: An Interpretation”, Muqarnas 3 (1985): 92.

78 The shops, bathhouses and houses generated income through their rental. Ana María Carballeira Debasa, Legados píos y fundaciones familiares en al-Andalus (siglos IV/X-VI/XII), (CSIC, 2002), pp.297-298.Luccioni, Les fondations, 126-129.Manuel Espinar Moreno, Baños árabes de Granada y su provincia: materiales para la arqueología y cultura material (Helsinki: Academia Scientiarum Fennica, 2014),p.108. Maya Shatzmiller, "Waqf Khayrī in Fourteenth-Century Fez: Legal, Social and Economic Aspects", Anaquel de estudios árabes 2 (1991): 197.

${ }^{79}$ Recent studies have proposed that the use of the bathhouse does not necessarily have to do with the required purification of the body, and that therefore, it plays a lesser religious role. Actually, it is a commercial facility that is part of the everyday life of the city and its location in the vicinity of a mosque corresponds to the logic of placing such a venue in a highly transited area. Caroline Fournier, Les Bains d'al-Andalus: VIIIe-XV siècle (Rennes: Presses Universitaires de Rennes, 2016), pp.234-243.

${ }^{80}$ This mosque had other ablution facilities associated to it, however they were not part of a unitary design. Alberto J. Montejo Córdoba, "El pabellón de abluciones oriental de la mezquita aljama de Córdoba correspondiente a la ampliación de Almanzor", Cuadernos de Madīnat al-Zahrā' 4 (1999): 209-231.

${ }^{81}$ Besides its close relationship with examples from the Saadian period, it is also important to highlight the large number of Marinid examples that have reached us and that therefore have been documented and/or studied.

${ }^{82}$ The correct name of this mosque is al-Zahr, although Maslow calls it al-Zhar and Cambazard-Amahan calls it al-Zar. Boris Maslow, Les mosquées de Fès et du nord du Maroc (Paris: Editions d'art et de histoire, 1937), p. 65. Catherine Cambazard-Amahan, "Arquitectura marīní”, La arquitectura del Islam occidental, coord. Rafael López Guzmán (Granada: Fundación El Legado Andalusí, 1995), p.222.
} 
of a larger size, such as the Great Mosque of New Fez, the mì $\bar{d} \bar{a}$ ' $a$ is a freestanding building in the vicinity of the mosque ${ }^{84}$. The mosque-madrasa of Abū 'Inān is telling among the Marinid examples, where the mosque, the madrasa, the minaret, the mī $\bar{a}$ ' $a$ and the shops are all designed as part of the same building ${ }^{85}$. However, two other references stand out given their similarity with the Saadian examples presented herein: the Sīdī Abū Madyan complex in Tlemcen and the al-Hamrā' mosque in Fez.

The first was founded by the Marinid sultan Abū al-Hasan (1331-1351) outside the city walls of Tlemcen next to the tomb of the renowned mystic Abū Madyan (Figure 13). The ensemble includes several buildings most of which are not attached to one another, instead they follow a dispersed layout. The mosque and the madrasa stand out given their size. To the east, a mī $\bar{a} \bar{a}$ ' $a$ and a hammām are located, while Abū Madyan's mausoleum, a royal palace, a residence for the custodian (wakil) and a house for pilgrims all stand to the north ${ }^{86}$. Even though we do not know whether all of these structures were part of Abu al-Hasan's original project, the studies that have been carried out consider that the mosque, madrasa, palace and $m \bar{\imath} d \bar{a}$ ' $a$ are works of the same sultan ${ }^{87}$. The complex has an orderly layout following two main orientations, that of the mausoleum, palace and residence of the wakill, and that of the mosque, madrasa and mīẹa' $a$.

The second example is a mosque built in New Fez (Figure 14). To us, its importance resides in the fact that it is the only case from the Marinid period in which we have been able to identify traits that also characterize the two Saadian examples in Marrakesh presented in this paper $^{88}$. On the one hand, the al-Hamrā' mosque and its annexes are located next to the main street of New Fez, an artery full of commercial life that connects Bāb al-Mašwar with Bāb al-Sammārīn, a superb location allowing it to establish a forceful relationship with its surroundings. On the other hand, it is a complex comprised of a congregational mosque, located on the eastern side of the street, with a group of annexes across the street from it: a $m \bar{\imath} \dot{a} \bar{a}$ 'a a hammàm, a fountain and shops. These buildings are part of a block set parallel to the aforementioned street, in contrast with the mosque, which has a different orientation. Nevertheless, this case must be considered cautiously, since the lack of further studies prevents us from clearly considering it a unitary design.

Without a doubt, during the Saadian period there was a continuation of the religious complex model seen in these two Marinid examples. However, it is also interesting to highlight the innovations introduced in our case studies with regards to these precedents.

\footnotetext{
${ }^{83}$ Maslow, Les mosquées, 65-68 and 80-85.

${ }^{84}$ Ibid., 53 and 64.

${ }^{85}$ Regarding this mosque see: Georges Marçais, L'architecture musulmane d'occident :Tunisie, Algérie, Maroc, Espagne et Sicilie (Paris : Arts et Metiers Graphiques, 1954), pp.286-290. Charles Terrasse, Médersas du Maroc (Paris: Albert Morance, 1927), pp.24-29. Lucien Golvin, La madrasa médiévale (Aix-en-Provence: Edisud, 1995), pp.245-247. Ahmed Ettahiri, Les madrasas marinides de Fes. Etude d'histoire et d'archeologie monumentales, Doctoral Thesis, March 1996, pp. 248-293. Ahmed Ettahiri "La Bu'inaniya de Fès, perle des madrasas mérinides", en Le Maroc médiéval. Un empire de l'Afrique à l'Espagne, eds. Lintz, Yannick and Déléry, Claire, París, Hazan, 2014,pp. 474-476.

${ }^{86}$ William Marçais, Les monuments arabes de Tlemecen, (Paris: Fontemoing, 1903), pp.224-284. Lucien Golvin, La madrasa, 202-205.

${ }^{87}$ Marçais, L'Architecture, 276 and 291. Agnès Charpentier, Michel Terrasse, Sidi Mohamed Negadi, L'image de Tlemcen dans les archives françaises. Catalogue de l'exposition (Tlemcen: centre Culturel Français de Tlemcen, 2011), p. 117.

${ }^{88}$ We would like to stress the fact that Marinid architecture also requires in-depth studies, since up until now researchers have focused only on the madrasa-s and some mosques. We insist that future investigations into Marinid mosques and their urban contexts will provide pleasant surprises.
} 
Besides their larger size, the variety of their annexes with their different spatial solutions, the main contribution of the Bāb Dukkāla and al-Muwāssīn complexes is the creation of public spaces. These spaces help organize the layout of the complex, structure internal connections and establish relationships with urban arteries. In our opinion, this approach is quite pertinent considering that the Saadian complexes were inserted into preexisting urban tissues.

Even though they differ greatly, Eastern Islamic cities also have enormous complexes that include several buildings (madrasas, hospitals, public canteens, hostelries, bathhouses or caravanserai, among others) which were widely built during the thirteenth and fourteenth centuries by the Seljuc and Mamluk dynasties, and after the fifteenth century by the Ottomans. The latter erected complexes (külliye) during approximately the same time as the Saadians. These were organized around a grid of wide orthogonal streets and squares that articulated the connections with the surrounding streets. The most relevant examples are the monumental complexes of sultans Mehmet II (Fatih) and Süleyman I in Istanbul ${ }^{89}$. The Fatih complex (erected between 1463 and 1470) was built, like many others, next to one of the city's main axes, Divanyolu street, which had existed ever since the Byzantine period, near an area full of commercial activity. It was erected, among other objectives, to revitalize the district $^{90}$. It has a set of independent monumental buildings with a mosque at the center, all laid out following an orthogonal plan which served as the pattern for the residential growth that took place later on around $\mathrm{it}^{91}$. This design was also implemented in other Ottoman facilities, among which the Süleymaniye complex must be highlighted.

However, we discard any Ottoman influences on the two Saadian case studies, since the composition of the ensemble responds, more probably, to more autochthonous models present in Fez and Tlemcen. Moreover, the in-depth study of the buildings in Marrakesh has showed us that local archetypes were always used during the Saadian period, especially Almohad precedents ${ }^{92}$. Nevertheless, knowledge of the Ottoman examples helps to understand the way in which these Islamic religious complexes were set in their context, their relationship with the city and their religious, social, economic and symbolic goals.

\section{Final Considerations}

Up until now, the study of Saadian religious complexes had focused on their mosques, while the existence of other buildings in their surroundings had only been pointed out, suspecting that they were probably constructions from the same period. In essence, we think that this formulation is correct, but the research and fieldwork that we have carried out in order to obtain a comprehensive plan of the mosques with all of their annexes in their urban

\footnotetext{
${ }^{89}$ Aptullah Kuran, “A spatial study of three ottoman capitals: Bursa, Edirne and Istanbul”, Muqarnas 13 (1996): 128-130. Kuban, Ottoman architecture (Woodbridge: Antique Collector's Club, 2010), pp.177-180 and 277-279.

${ }^{90}$ Maurice Cerasi, "The urban and architectural evolution of the Istanbul Divanyolu: Urban aesthetics and ideology in Ottoman town building", Muqarnas 22 (2005): 195-199. Kuban, Ottoman architecture, 177.With regards to this, the examples built by officials in Aleppo are of equal interest, especially that of Hüsrev Paşa, inserted in the commercial center of the city and connected with the main streets. Çiğdem Kafesçioğlu, "In the Image of Rum: Ottoman Architectural Patronage in Sixteenth-Century Aleppo and Damascus" Muqarnas 16 (1999): 71-73.

${ }^{91}$ Maurice Cerasi, "The urban and architectural”, 199. This growth took place hierarchically throughout the city. The viziers developed the rest of the urban space by means of smaller centers and less important streets. Maurice Cerasi, "The urban and architectural", 211.

92 The Almohad works of Marrakesh, specifically the Kutubiyya mosque and the mosque of the Qașba determined the layout of the plans of the Saadian mosques, the solutions applied to their facades and the design of their minarets.
} 
setting has demonstrated that the issue at hand is much more complex. Regardless of the fact that some of the buildings have been transformed or added in later years, most of the structures seem to correspond to the same building enterprise, encompassing a mosque, annexes and public spaces. This characteristic is perceptible in their shared architectural language, the interrelationship of the different components and their coordinated layout, following one or more orientations.

In fact, the construction of both complexes had quite remarkable impact on the urban tissue, given that these architectural ensembles of a monumental scale were inserted into densely populated residential areas, as is the case of al-Muwāssīn, or in sparsely occupied and practically agricultural contexts, as is the case of Bāb Dukkāla. In both cases, the sheer volume of these buildings has made them architectural landmarks in the urban landscape, thanks to their minarets, gates, facades and squares. In addition, their construction involved the generation of economic activities and social relationships that had did not exist in those enclaves previously. In this sense, commercial activities proliferated along the main arteries, the new squares and the perimeter of the mosques, while the hammām and the mī $\bar{a} \bar{a}$ ' $a$ became invaluable facilities for the community, serving not only the neighbourhood, but also attracting the rest of the city. Therefore, the construction of these complexes entailed the radical transformation of these neighbourhoods, breaking their isolation and connecting them with the city as a whole.

The two cases we have presented were part of a larger scheme that strove to revitalize the city of Marrakesh, providing it with new facilities and reactivating the economic centers of the medina. The main figure behind this enterprise was sultan 'Abdallāh al-Ghālib, to whom these works are attributed and who had first-hand knowledge of the city of Fez, where he found references for his projects in the interventions carried out by the Marinid dynasty in the fourteenth century.

Concerning their physiognomy, the two Saadian examples presented herein implemented the same ideas and models and even used the same archetypes, to such an extent that the differences between the two are determined almost exclusively by the contingencies of each of their settings. As we have seen in our analysis of the urban context, the layout of both complexes tries to make the most of the urban tissue in which they are set, that is, they take advantage of the connectivity offered by the main arteries. However, the existing street alignments and the availability of space prevented the complexes from sharing the same formal layout, especially in the case of the al-Muwāssīn example, where a denser residential and commercial tissue existed prior to its construction. In contrast, the Bāb Dukkāla complex was laid out more freely due to the relatively uninhabited nature of the area around it.

In addition, these two case studies contribute to characterize the architecture of the Saadian period, allowing us to identify traditional features, as well as innovations and singularities incorporated into the design of these two complexes. Regarding this last aspect, we must highlight the presence of squares - understood as purposely designed public spaces - as part of their architectural composition and how they represent an atypical component in the urbanism of the Islamic West. These squares are spatial innovations that may respond to formal needs, but they are also successful urban design tools used here to connect these new constructions with the pre-existing urban context.

To conclude, we believe that the work carried out to contextualize these architectural works in space and time has produced a new understanding of the impact of their construction in the city and, therefore, of the ambitions and capability of the Saadian sovereigns to carry 
out monumental projects. Moreover, behind these interventions is the idea of recovering the city by building mosques and related facilities as catalysts of urban life in the sixteenth century. 